\title{
HERÁCLITO, B 52 DK: CONTRIBUIÇÃo À SEMÂNTICA DO JOGO
}

\author{
André Pereira Leme Lopes ${ }^{1}$
}

\begin{abstract}
Resumo: O fragmento B 52 DK de Heráclito define aiốn ("tempo", "vida”, ou "duração da vida") como uma criança brincando/jogando. Qual é, no entanto, o jogo/a brincadeira dessa criança? A interpretaçấo mais comum desqualifica o jogo heraclítico, elencando esse fragmento dentre aqueles nos quais o filósofo critica o conhecimento falho dos homens. Na contramão dessas, propốe-se neste texto uma análise filológica que pode oferecer algumas sugestóes para melhor identificar e compreender o jogo de B 52, acreditando que náo se trate de uma brincadeira infantil, mas, de fato, de um jogo sério que ressoa com metáforas cósmicas e cívicas.
\end{abstract}

Palavras-chave: Jogo. Heráclito. Filosofia grega.

\section{INTRODUÇÃO: O FRAGMENTO}

Dentre os fragmentos costumeiramente atribuídos a Heráclito de Éfeso (c. 540-470 a.C.), aquele catalogado sob o n. ${ }^{o} 52$ por Hermann Diels e Walter Kranz se destaca por sua singularidade. O professor de Filosofia da Universidade Federal Fluminense (UFF) Alexandre Costa (2002, p. 254), por exemplo, ao reorganizar, traduzir e contextualizar os aforismos do présocrático, deixou-o para o final, isolado "por falta de paralelo". O filólogo, partisan e professor de origem sérvia Miroslav Marcovich (1967, p. 474s), por sua vez, classificou-o junto aos fragmentos 78, 79 e 102, mas o destacando com um ponto de interrogação e o qualificando como "enigmático". Já o professor emérito da Universidade da Pensilvânia Charles H. Kahn (2001, p. 227), o chamou de "o mais enigmático dos quebra-cabeças heraclíticos".

Até mesmo linguisticamente, a curta frase se destaca. Formada por seis termos centrais (mais um verbo e um artigo), três são únicos no corpus do

${ }_{1}$ Professor de Teoria e Metodologia da História na Universidade de Brasília (UnB), Brasília, DF Brasil. (D) https://orcid.org/0000-0002-9213-1184 E-mail: aleme@gmx.us

https://doi.org/10.1590/0101-3173.2021.v44n1.02.p17

\section{(i)}


efésio, os demais constituem variaçóes gramaticais da mesma palavra (i.e., a figura de linguagem conhecida como poliptoto). ${ }^{2}$

$\mathrm{Na}$ literatura supérstite, o texto aparece pela primeira vez em Luciano de Samósata (c. 125-180 d.C.), seis séculos após a morte do pré-socrático. No diálogo Leilão dos filósofos (c. 160-170 d.C.), diversos pensadores são oferecidos em um mercado de escravos para escrutínio de um comprador. Ao chegar diante de "aquele de Éfeso" (seção 14), o comprador ouve que todas as coisas estão misturadas e são intercambiáveis "no jogo de aiòn" (en tề tồ aiônos paidiêे). O comprador pergunta: "e o que é o aiốn" e o efésio responde: "paîs paizōn, pesseúōn [...]” (LUCIAN, 1960, p. 476-477).

Meio século depois, Hipólito de Roma (170-235 d.C.), no livro IX de sua Refutação de todas as heresias (c. 225 d.C.), também conhecida como Elenchus ou Philosophumena, fez o que se acredita ser "um abrangente sumário das principais doutrinas de Heráclito” (BARNES, 1997, p. 119). O trecho é bastante longo e nos oferece a redação mais completa do fragmento 1 (que já aparecia na Retórica de Aristóteles, c. 335-320 a.C.) e dos fragmentos 50 a 67, na numeração de Diels e Kranz. É nesse contexto que aparece o texto canônico de nossa sentença: aiòn paîs esti paízōn, pesseúōn: paidòs hē basilếée.

Antes de avançarmos à tradução e à interpretação, paremos um instante para apreciar a poética. B 52 é marcado pela aliteração do fonema "p-" em seu centro: "paîs ... paízōn, pesseúōn: paidòs...”. Após a definição simples, "aiòn é paîs", dois particípios criam um contraponto em "-oon”, o qual retoma a sonoridade da primeira palavra: "ai $\underline{\underline{o} n}$... paizōn, pesseúōn", assim como os ditongos marcam uma terceira aliteraçáo nas palavras iniciais da frase

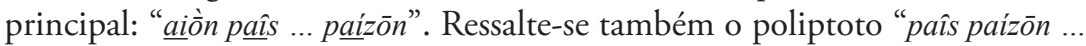
paidós" ("criança" "sendo criança” ... "da criança”). Se o fragmento diz respeito ao jogo, como discutiremos adiante, ele o faz por meio de jogos de palavras cuidadosamente escolhidas (MOST, 2011, p. 105; SILVA, 2013, p. 96).

A poesia de Heráclito foi percebida pelo poeta brasileiro Haroldo de Campos (1974, p. 218), tradutor de Homero, Dante, Mallarmé, Goethe e Maiakovski, que assim transcriou nosso fragmento:

${ }^{2}$ Embora as palavras aiòn, pesseúōn e basilêée não apareçam em nenhum outro fragmento atribuído a Heráclito, deve-se observar que basileús (rei, chefe), lexicamente próximo de basilêéé (reino, reinado), aparece no fragmento B 53. Os demais vocábulos de B 52 são variaçốes de paîs, que, em diversas funçôes gramaticais, aparece em pelo menos sete fragmentos: B 20, 52, 56, 70, 74, 79, 117 (BOLLACK; WISMANN, 1972, p. 372, 374, 381). 


$$
\begin{aligned}
& \text { vidatempo: } \\
& \text { um jogo de } \\
& \text { criança. } \\
& \text { (reinando } \\
& \text { o Infante } \\
& \text { Infância) }
\end{aligned}
$$

\section{TraduÇốES E INTERPRETAÇóES}

A frase é formada por um sujeito (aiòn), um verbo (esti), um predicativo (paîs ... paízōn, pesseúōn) e um aposto (paidòs hē basilêêê). As traduçóes costumam ser bastante consistentes, variando principalmente no que diz respeito ao sujeito. Como esse é, precisamente, objeto da definição expressa no predicativo, as interpretaçôes são bem mais diversificadas. Apesar disso, podemos, sem grandes hesitaçóes, traduzir parcialmente nosso fragmento por: aiốn é criança brincando, jogando; da criança o reinado (OS PRÉSOCRÁTICOS, 1996, p. 93; COSTA, 2002, p. 218).

Desse modo, Diels e Kranz (1960, p. 162), por exemplo, traduziram o predicativo e o aposto como "ein Knabe, der spielt, hin und her die Brettsteine setzt: Knabenregiment?" (um menino que brinca, mexendo de um lado a outro as peças do tabuleiro: regimento dos meninos!); o erudito italiano Giorgio Colli (1980, p. 35) escolheu "un fanciullo che gioca, che sposta i pezzi sulla scacchiera: reggimento di un fanciullo" (uma criança que joga, que move as peças sobre o tabuleiro: regimento de uma criança); e o professor emérito da Sorbonne Marcel Conche (1998, p. 446) preferiu "un enfant qui joue en déplaçant ses pions : la royauté d'un enfant" (uma criança que joga movendo seus pióes: a realeza de uma criança).

Quanto às interpretações, Geoffrey Stephen Kirk, em seu livro Heraclitus: the cosmic fragments (1954), dividiu o corpus do filósofo em duas partes, aquela que diz respeito ao "mundo em geral" (os "fragmentos cósmicos" do título) e aquela que fala sobre os "ocupantes humanos" desse mundo. "À primeira vista”, afirma ele, nosso fragmento poderia ser classificado entre os da primeira parte, pois hē basilèiée, "a realeza", "o poder real", poderia ser compreendido como o governo "sobre todas as coisas absolutamente". O renomado classicista de Cambridge, no entanto, rejeita tal interpretação, com 
base no sentido de aiốn, o qual, "nos contextos arcaicos e usada sozinha (i.e., não em frases preposicionais)” referia-se à vida humana (KIRK, 1962, p. xiii).

De forma geral, as interpretaçóes modernas seguem a classificação de Kirk, se não para o conjunto dos fragmentos de Heráclito, ao menos para interpretar B 52.

Assim, por exemplo, os filólogos e filósofos Jean Bollack e Heinz Wismann (1972, p. 402-403), embora critiquem Kirk, argumentando que ele faz uma "simplificação ilusória" e que a tese expressa em seu título é "errônea", colocam-se ao lado do professor de Cambridge, ao tratar B 52 como se referindo a questôes humanas. Segundo a dupla franco-alemã, entre aiốn e basiléié, todas as demais palavras concernem à infância. Os dois particípios centrais - paizōn pesseúōn - são entendidos como "quase sinônimos" e, "por etimologia", paizón - literalmente "fazendo o que uma criança faz" - é reinterpretado como "fazendo uma criança" (BOLLACK; WISMANN, 1972, p. 182ss). Logo, o fragmento - traduzido por ambos como "La vie est bien un enfant qui enfante, qui joue. À l'enfant d'être roi" (A vida é uma criança que dá à luz, que joga. À criança, de ser rei) - diria respeito à sucessão das geraçóes e à transformação da criança em adulto:

O aiôn [tempo da vida] (de um homem) compreende a criança nascida dele e se cumpre quando o filho equivale a seu pai. [...] Em um jogo, cada um toma a iniciativa por sua vez. [...] O filho joga contra seu pai, que tem a iniciativa durante quinze anos, enquanto ele for filho, mas quando toma a realeza, joga contra seu próprio filho e é substituído, como parceiro, pelo avô. O ciclo da vida se resolve em um crescimento e um contracrescimento, saído dele. [\$] A terceira criança (à criança, de ser rei) é, portanto, também a primeira, o filho, investido das funçôes de seu pai. (BOLLACK; WISMANN, 1972, p. 184).

Miroslav Marcovich (1967, p. 493-495) também concorda com Kirk, em relação à "humanidade" de B 52, propondo que aiốn implique "idade madura e velhice do homem". Aproximando-o de outros fragmentos que expressam a estupidez e a falta de percepção dos homens (e.g., B 56, 78, 79, 102 e 121 DK), o filólogo "se aventura" a "sugerir" a seguinte interpretação para o "sentido obscuro" do texto: 
[...] um homem maduro ou velho é tão tolo quanto o é uma criança, em qualquer respeito e especialmente em relação à sabedoria ou ao discernimento político: um rei no trono se comporta como uma criança.

As interpretaçôes "cósmicas", por sua vez, seguem a doxografia antiga, a qual entende aiốn como um agente universal. Dentre as tradicionais, Marcovich (1967, p. 490-491, 493) destaca: 1) a (má) interpretação órfica de aiốn como Deus/Zeus (Æon); 2) a referência de Clemente de Alexandria (c. 150-215 d.C.) a um "jogo divino" (theía paidiá) jogado pelas crianças em Cristo (en Christồi paidíonn) e a afirmação do mesmo de que "Heráclito diz que seu Zeus jogava um jogo (paizein paidiàn) desse tipo"; e 3) a menção do neoplatônico Proclo (412-485 d.C.), que, em seu comentário ao Timeu, escreveu que Heráclito era um dos que defendiam que "o Demiurgo joga ao criar o mundo" (tón dēmiourgón én tối kosmourgeïn paízein) (ŠĆEPANOVIĆ, 2015, p.28-32). ${ }^{3}$

Dentre os modernos, Martin Heidegger discutiu o aforismo, em seu Der Satz von Grund (1956), argumentando que lógos, kósmos, phýsis e aiôn, no vocabulário de Heráclito, são aspectos do Ser, seu entrelaçamento nas palavras/ ideias (lógos) ou nas coisas do mundo (phýsis), sua organização e sua beleza (kósmos), seu aspecto temporal (aiốn). Em nosso fragmento, portanto, aiốn seria o "tempo do mundo"; o "fazer mundo e temporalizar" (die weltet und zeitigt), que ele traduz por Seinsgeschick (destino/habilidade do Ser). A temporalidade do Ser é uma criança que joga; a essa criança pertence a arché, o princípio, o fundamento da ordem, do governo e da existência, ou seja, o próprio Ser, que, "[...] como aquilo que funda, não tem fundamento (Grund); joga como o abismo sem fundo (Ab-Grund) aquele jogo que, enquanto Geschick, nos dá (zuspielt) o Ser e o Fundamento." (HEIDEGGER, 1997, p. 169).

Também Clémence Ramnoux (1959, p. 399) aproximou o fragmento da ontologia. A partir de aiốn, a erudita francesa leu aei ōn, "sempre existente", e, tomando-o juntamente com paizōn, aei zoōn, "sempre vivo" (Charles Kahn (2001, p. 228) também reconhece esses jogos de palavras). Além disso, em

\footnotetext{
3 Sandra Šćepanović (2015, p. 31) chama a atenção para o fato de que o Demiurgo é provavelmente uma extrapolação de Proclo a partir de Platão, uma vez que não há menção a um Demiurgo ou a qualquer figura criadora no corpus sobrevivente do filósofo de Éfeso. Ao contrário, B 30 DK, que conhecemos por Clemente de Alexandria, afirma: "[...] este mundo (kósmos), o mesmo de todos os (seres), nenhum deus, nenhum homem o fez, mas era, é e será um fogo sempre vivo, acendendo-se em medidas e apagando-se em medidas." (OS PRÉ-SOCRÁTICOS, 1996, p. 90).
} 
paîs paizōn, Ramnoux decifrou o nome de Pan e, em paizōn pesseúōn, o nome de Zeus. Com isso, aproximou B 52 do verso de Ésquilo, contemporâneo de Heráclito: "qualquer divindade suprema, Apolo/ou Pan ou Zeus" (býpatos d'aiōn é tis Apóllōn / è Pàn è Zeùs, Agamêmnon, vv.55-56). Assim, os nomes divinos - e Heráclito os usa esporadicamente - seriam equivalentes do sempre vivo e sempre existente, o Ser.

Não é meu objetivo listar todas as leituras desse singular fragmento de Heráclito, todavia, no momento, apenas apontar algumas tendências interpretativas mais comuns. Sandra Šćepanović (2015, p.33) faz uma breve lista dos leitores modernos, dividindo-os segundo a classificação de Kirk. Deixemo-los de lado por um instante e tentemos discutir o fragmento em si, analisando diretamente os termos que dizem respeito a nosso objeto, o jogo (ou seja, os particípios paízōn e pesseúōn).

\section{OS PARTICÍPIOS CENTRAIS}

O primeiro particípio, paízōn, deriva de paîs, "criança”, e significa literalmente "se comportar como uma criança", donde "brincar" e sentidos derivados, como "jogar um jogo", "dançar", "tocar um instrumento musical"

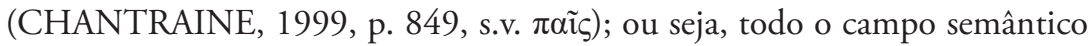
de verbos comuns nas línguas ocidentais, como jugar (esp.), giocare (it.), jouer (fr.), играть (rus.), spielen (ale.), spelen (hol.), to play (ingl.).

Já o segundo, pesseúōn, deriva do jônico pessós, "pedra oval”, "peça de jogo" e significa literalmente "jogar um jogo com pessol", donde "jogar com pedras", "jogar com peças" ou "jogar um jogo de tabuleiro" (CHANTRAINE, 1999, p. 890, s.v. $\pi \varepsilon \sigma \sigma o ́ \varsigma)$.

Paizōn, portanto, indica uma atividade genérica - brincar/jogar - e pesseúōn a especifica: jogar um jogo de tabuleiro com peças.

\section{Jogos DE TABULEIRO}

Parece ter havido duas formas distintas desses jogos na Grécia, por volta da época em que Heráclito viveu. ${ }^{4}$ A primeira seria um jogo chamado

\footnotetext{
${ }^{4}$ Deve-se observar que a evidência sobre os jogos de tabuleiro gregos do período arcaico é bastante escassa e fragmentária, além de ser, na maior parte das vezes, tardia. Consequentemente, é impossível confirmar o formato dos tabuleiros ou as regras desses jogos e até mesmo nomes, funçôes ou quais as
} 
pólis, aludido por Platão (República, IV, 422e; PLATO, 1994, v. 5, p. 324327): "[...] devemos chamar às outras de forma mais ampla, pois cada uma das outras cidades (póleis) são muitas e não uma cidade (pólis), como no jogo (tò tồn paizóntōn).”

Provavelmente, trata-se do mesmo jogo descrito por Júlio Pólux (gramático e sofista ativo por volta de 180 d.C.) e por Eustácio, bispo de Tessalônica (c. 1115-1195):

O jogo jogado por meio de muitas peças (pollôn psếphōn) é um tabuleiro (plinthion) que possui espaços dispostos em linhas; e o tabuleiro é chamado de "pólis" e cada uma das peças é um "cachorro". As peças são divididas em duas por cor e a arte do jogo é capturar as peças da outra cor, rodeando-as com duas da mesma cor (Pólux, Onomástica, IX, 98 apud KURKE, 1999, p.256). ${ }^{5}$

Existe uma outra forma do jogo "pólis" em que a tomada de peças ocorre para frente e para trás quando muitas peças foram colocadas em espaços divididos por linhas. E eles costumavam chamar, com bastante espirituosidade, os espaços delimitados pelas linhas "poleîs" e as peças que se opóem umas às outras como "cães", por conta (suponho) de sua falta de vergonha. (EUSTÁCIO, Comentário à Odisseia, I, 107 apud KURKE, 1999, p. 255, n. 21).

Sabemos que esse jogo existia desde fins do século $V$ a.C., pelo menos, já que Pólux cita uma passagem de Crátino (comediógrafo ateniense, c. 520-423 a.C.), para ilustrar o uso dos termos pólis e kýon ("cão") (KURKE, 1999, p. 256).

A outra forma parece ter sido um jogo identificado como pénte grammaí (“cinco linhas"), que aparece em um verso de Sófocles (fr. 429). Pólux o descreveu assim:

[...] cada um dos que jogavam tinha cinco [peças] em cinco linhas, de modo que é dito adequadamente em Sófocles, "tabuleiros de cinco linhas (pessà pentégramma) e lançamentos de dados". E das cinco linhas de cada lado (em cada direção?) havia uma no meio, chamada de "linha sagrada"; aquele que moveu a peça de lá fez o ditado "sair da linha sagrada" (Onomástica, IX, 97-98 apud KURKE, 1999, p. 257; tb. AUSTIN, 1940, p. 267-268).

peças utilizadas nos jogos. Às vezes, é difícil até mesmo precisar se a evidência literária se refere a um mesmo jogo ou a jogos diferentes (ver, e.g., o verso de Sófocles discutido infra).

${ }^{5}$ As peças de jogo, pessoí (ático pettoì), também eram chamadas eventualmente de líthoi (pl. de líthos, "pedra") ou psê̂phoi (pl. de psê̂phos, "seixo", "pequena pedra redonda e gasta", normalmente usada para contagem, votações e adivinhação). 
Eustácio de Tessalônica acrescentou que o "movimento da linha sagrada" era o último recurso para um jogador que estava sendo derrotado, "[...] de onde o provérbio "sair da linha sagrada" para [indicar] pessoas que estão desesperadas e precisam definitivamente de ajuda.” (KURKE, 1999, p. 257). O bispo citou o provérbio em passagens de Teócrito (poeta siciliano ativo por volta de 270 a.C.), Sófron de Siracusa (fl. c. 430 a.C.) e Alceu de Mitilene (poeta lírico, c. 620-580 a.C.), o que sugere que pénte grammai pode datar do século VI a.C. (AUSTIN, 1940, p. 268).

Dois detalhes são importantes e merecem um pouco mais de consideração.

Em primeiro lugar, ambos os jogos, conforme descritos, parecem ser um "jogo de batalha", ou seja, um tipo de jogo no qual o objetivo é controlar o tabuleiro com suas peças e que, em geral, náo usa dados (AUSTIN, 1940, p. 259). O verso de Sófocles, no entanto, menciona explicitamente lances de dados. É bem verdade que não conhecemos seu contexto e, portanto, não podemos ter certeza de que os dados fossem usados no tabuleiro de cinco linhas referido na primeira parte do verso. Pergunto-me, porém, por que Pólux citaria o verso "completo", ou seja, incluindo a referência aos dados, se o jogo não os empregasse - ele poderia perfeitamente citar apenas a primeira parte do verso.

Além disso, em uma série bastante popular de vasos áticos do período arcaico (c. 540-480 a.C.), a imagem de dois hoplitas jogando um jogo de tabuleiro é acompanhada de inscriçóes próximas à cabeça dos guerreiros com números que, se acredita, se referem a lances de dados anunciados pelos jogadores (MARISCAL, 2011, p. 394, n. 3). Assim, acredito haver evidências de que pelo menos um tipo de jogo de tabuleiro grego usava peças $e$ dados, no período arcaico.

Segundo detalhe: uma referência a pénte grammaí, no escólio a Teócrito, assevera que a peça que saía da linha sagrada era chamada "rei", basileús (KURKE, 1999, p. 257, n.28).

Roland Austin (1940, p. 258) e a maior parte dos eruditos modernos descartam esse comentário, com base na palavra zatrikion, "xadrez", usada pelo escoliasta em conexão com petteía, "jogo de tabuleiro”, o que parece sugerir 
que o comentarista mistura jogos diferentes, os petteía gregos da época arcaica/ clássica e o xadrez recém-importado do Oriente. ${ }^{6}$

No entanto, na passagem de Alceu citada por Eustácio para confirmar o provérbio supracitado, lê-se: "mas este agora governa (epikrétei), tendo movido a peça da linha sagrada.” (EUSTÁCIO, fr. 351 apud KURKE, 1999, p. 257, n. 28). Se considerarmos que essa passagem diz respeito ao governo de Pítaco (c. 640-568 a.C.), contemporâneo e conterrâneo de Alceu, a ideia de que uma peça em um jogo de tabuleiro estava conectada à "realeza" parece ter evidências mais seguras. Pítaco foi tirano eleito (aisymnétēs) em Mitilene, na ilha de Lesbos, mas uma antiga música preservada por Plutarco indica que o título de basileus, "rei", era usado para denominá-lo: "Moer, moer, moer; pois até Pítaco mói, aquele que é basileús na grande Mitilene.” (KURKE, 1999, p. 257, n. 28). Segundo Leslie Kurke (1999, p.257), “[...] o poeta [Alceu], amarga e desdenhosamente, caracteriza seu oponente como (meramente) a imitação de um rei em um jogo de tabuleiro."

Em outra referência, um pouco posterior e em uma passagem bem mais complexa e obscura, Platão chama o petteutếs (jogador de jogos de tabuleiro) de "rei" (PLATÃO, Leis, X, 904a; KAHN, 2001, p. 227, n. 302).

E por que esses detalhes são importantes para nós? Porque, voltando a nosso fragmento, talvez o aposto paidòs hé basilééé possa ser entendido como "da criança [é] a peça do rei". Mesmo que não possamos identificar com certeza o jogo de B 52 com pénte grammai (e que não possamos ter certeza de que esse jogo tivesse uma peça chamada "rei”), havia diversas outras atividades na Grécia que brincavam com a realeza. Basilínda, citada por Heródoto (I, 114), era uma brincadeira infantil na qual uma das crianças era escolhida/ sorteada "rei" e dava ordens às outras, que deveriam cumpri-las. Outro jogo, citado por Pólux (Onomástica, IX, 106), era jogado com bola e o vencedor era nomeado "rei", enquanto o perdedor, "burro" (CANCIK et al., 2006, s.v. Basilinda). Ou seja, é uma suposição razoável interpretarmos nosso aposto, paidòs hē basilêeiê, como uma indicação de que a criança que joga com pessoí, em B 52, "conquistou o reinado" ou "tornou-se rei" por capturar a peça do rei e/ou vencer o jogo.

De outro ponto de vista, Charles H. Kahn, aceitando que algum jogo de tabuleiro antigo utilizasse dados e peças simultaneamente, sugere que B 52 pode

${ }^{6}$ Petteía (equivalente ao jônico pesseía) é um termo ático genérico usado para indicar um jogo de tabuleiro qualquer. A passagem de Teócrito comentada apenas traz "e das linhas moveu a peça" (kaì tòn apò grammâs kineî lithon, VI, v. 18; THEOCRITUS, 1973, p. 52). 
ser lido como a interação de uma força aleatória (os lançamentos de dados) com o movimento regrado e ordenado das peças em um jogo de tabuleiro:

Do meu ponto de vista, a questão fundamental não são os movimentos infantis e aleatórios do jogo (como alguns intérpretes supuseram), mas o fato de que esses movimentos seguem uma regra definitiva e depois que um lado joga é a vez do outro e depois que a vitória é alcançada, o jogo deve ser reiniciado. As regras do jogo de pessoí, portanto, imitam as medidas alternadas do fogo cósmico. (KAHN, 2001, p. 227; B 30 DK, supra, n.1).

À primeira vista, pode parecer estranho usar um frívolo jogo de tabuleiro como metáfora de questôes táo importantes quanto o movimento do fogo universal, porém, essa sentença de Heráclito não é a única instância em que aproximaçôes desse tipo podem ser lidas.

\section{Jogos EM OUTROS FRAGMENTOS}

Em B 88 DK, por exemplo, lê-se: “[...] o mesmo é em (nós?) vivo e morto, desperto e dormindo, novo e velho; pois estes, tombados além, são aqueles e aqueles de novo, tombados além, são estes.” (OS PRÉ-SOCRÁTICOS, 1996, p. 97). O termo traduzido por José Cavalcante de Souza como "tombados além" é metapesónta, verbo que significa literalmente "cair de forma diferente", donde deriva a ideia de mudança que aparece nesse fragmento. Charles Kahn (2001, p. 227) observa que, em seu sentido literal, metapesónta poderia referirse ao lançamento de dados, o que sugeriria que o movimento dos opostos (tema recorrente e fundamental no pensamento do filósofo efésio) estivesse alinhado a um componente lúdico.

Mesmo se descartarmos o uso de dados nos jogos de tabuleiro gregos, metapesónta ainda traz ressonâncias que o ligam aos jogos de pessoí, pois esse verbo é sinônimo de metatithemi e metabállo, os quais eram usados para descrever o movimento de peças em um tabuleiro. Encontramos esses três verbos associados ao jogador de pessoi em uma "misteriosa" passagem de Platão, "literalmente assombrada por reminiscências heraclíticas" (KAHN, 2001, p. 227, n. 302):

E como a alma, sendo unida agora a um corpo, depois a outro, está sempre sofrendo (metabállei) todos os tipos de mudanças (metabolàs) seja por si mesma, seja pela ação de uma outra alma, ao jogador $\left(t \widehat{o}_{\mathfrak{c}}\right.$ petteutę $\overline{)}$ não resta outra tarefa senão transferir (metatithénai) o caráter que se aprimora para 
um lugar superior, o que piora para um pior, de acordo com o que melhor se ajusta a cada um a sorte que lhe cabe. [...] Todos os seres animados se transformam (metabállei) já que possuem dentro de si mesmos a causa da transformação (tê̂s metabolềs aitían), e ao se transformarem (metabállonta) se movem de acordo com a lei e a ordem predestinada; quanto menor for a mudança (metabállonta) da qualidade (dos seres), menor será seu movimento horizontal no espaço e quando a transformação (metapesónta) for acentuada e inclinada para a grande iniquidade, os seres se moverão rumo às profundezas e às chamadas regiōes inferiores [...] (PLATÁO, Leis, X, 903d, 904c-d; PLATÃO, 2010, p. 424-426).

Em outra situação, o filósofo de Éfeso parece opor o jogo à atividade política (embora, nesse caso, se trate de um jogo de natureza bem diferente dos pessoi). É Diógenes Laércio (180-240 d.C.) quem nos conta:

E quando seus concidadãos the pediram para elaborar leis, ele se recusou porque a cidade já estava submetida a uma constituição má. Retirou-se para o templo de Ártemis e foi jogar ossinhos (ēstragálize) com as crianças, apostrofando os efésios que estavam a sua volta com as palavras: "por que vos admirais, canalhas? Não é melhor fazer isso do que participar convosco do governo da cidade (politeústhai)?” (IX, 2-3; DIÔGENES LAÊRTIOS, 2008, p. 251).

Astragalízō, "jogar com astrágaloi" (pequenos ossos do tornozelo, que, em português, se chamam "tálus"), era uma forma de jogar na qual se empregavam cinco ossinhos que cada criança deveria lançar ao ar e tentar pegá-los, na parte de trás de uma das máos; quem pegasse o maior número ganhava. Essa história tira seu interesse da "preferência incongruente do falante pelos jogos infantis à seríssima atividade da lei” (KURKE, 1999, p. 259). E, no entanto, Leslie Kurke aponta que, em certo sentido, o paradoxo é duplo: jogos infantis são muito sérios para as crianças que os jogam, enquanto "elaborar leis" (nómous theînai) é uma atividade simbólica, tanto quanto jogar um jogo de tabuleiro. Assim, a professora de Berkeley sugere que Heráclito, talvez, não esteja opondo um jogo (ēstragálize) à "vida real” (politeústhai), mas "um tipo de jogo a outro, em um esforço para ensinar aos seus concidadáos uma lição objetiva” (KURKE, 1999, p. 259).

Nesse sentido, o termo politeústhai poderia trazer em si uma ambiguidade, significando ao mesmo tempo "participar da vida pública na 
cidade” e “jogar pólis”. A ressonância cívica dos jogos de tabuleiro é o principal assunto sobre o qual Kurke (1999, p.260) discorre, em todo o seu artigo:

[...] para (alguns) gregos dos períodos arcaico e clássico, jogar pessoí ensinava ao jogador como ser um cidadáo na pólis. Para o jogo chamado pólis, isso era verdade em pelo menos dois sentidos. Estritamente, as regras e a estratégia desse jogo de batalha imprimiam em seus jogadores a importância de manter seu lugar na linha de batalha dos hoplitas, em vez de se tornarem $\alpha$ $\zeta v \xi$, "isolados" (e, portanto, os pessoí alinhamse apropriadamente com as táticas militares, o primeiro item da lista de Górgias). Mais amplamente, o jogador aprendia o que significava submeter-se às regras e à ordem simbólica da cidade que o constituíam como um cidadáo com status igual a todos os outros cidadáos.

Metáforas ligadas a outros tipos de jogo aparecem ainda em B 120 DK: "limites de aurora e crepúsculo (são) a ursa e em face (antíon) da ursa a baliza do fulgurante Zeus" (OS PRÉ-SOCRÁTICOS, 1996, p. 100). Trata-se, mais uma vez, de um fragmento bastante discutido e traduzido de diversas formas. Andrei Lebedev (1985, p. 132), contudo, faz algumas observaçóes interessantes: a palavra térmata ("limites") significava literalmente o marco a ser contornado em uma corrida, como pode ser visto na Ilíada (XXIII, vv. 309, 333, 358, 462, 466) ou em Píndaro (poeta lírico contemporâneo de Heráclito; Píticas, IX, v. 114).

Assim, nessa imagem heraclítica, a aurora (ēoûs) e o crepúsculo (hespéras) seriam corredores que deveriam contornar dois marcos: a ursa e a "baliza do fulgurante Zeus" (oûros aithríou Diós). A ursa refere-se à constelação da Ursa Maior, que culmina no céu durante o equinócio de primavera. Já aithriou Diós, literalmente "Zeus/céu brilhante", era uma expressão arcaica para indicar "bom tempo" e, portanto, oûros aithriou Diós poderia indicar o "limite/fim do bom tempo", ou seja, o equinócio de outono (LEBEDEV, 1985, p. 131-132).

B 120, por conseguinte, retrata a aurora e o crepúsculo em uma corrida cósmica em direção a dois térmata, os equinócios, os quais, não esqueçamos, são as únicas ocasiōes do ano em que a duração do dia e da noite são iguais. Ambas as balizas estariam colocadas "opostas" (antion) uma à outra, como era o caso, por exemplo, no estádio de Olímpia. Por fim, resta observar que ánō ("para cima”) e kátō ("para baixo") eram termos técnicos de corrida que indicavam duas formas de correr na pista, o que nos leva a outro fragmento do efésio, pois, se colocarmos dois corredores no meio da pista e eles correrem com a mesma velocidade em direção aos térmata opostos, um correndo "para 
cima" e outro correndo "para baixo", ambos se encontrarão face a face no meio do estádio, comprovando que "a rota para cima e para baixo é uma e a mesma" (hodós ánō kátō mía kaí ốutè, B 60 DK; OS PRÉ-SOCRÁTICOS, 1996, p. 94; LEBEDEV, 1985, p. 133).

\section{SERIEDAde Do Jogo}

Considero importante mencionar B 120 e B 60, a fim de mostrar que Heráclito usou metáforas relacionadas a jogos, para discutir questóes cósmicas em mais de um fragmento. Todavia, não posso deixar de lembrar que, na Grécia, a corrida era designada pelo termo agốn ("disputa", "competição"), enquanto jogos como os de tabuleiro e os jogados com astragáloi ou bola eram referidos por outra palavra: paidiá, a qual, assim como paízōn, derivava de paîs, "criança". Ou seja, etimologicamente, jogos de tabuleiro eram "jogos/ brincadeiras de criança”".

Não obstante, não é difícil encontrar referências de que os jogos de pessoí eram considerados uma atividade séria e de maneira nenhuma restrita a crianças. Platăo, por exemplo, em mais de uma ocasião, destacou "jogar um jogo de tabuleiro" como uma atividade importante. No Górgias, ele a incluiu entre diversas artes (tồn technồn) mentais:

Há, pelo contrário, outras artes que realizam todos os seus objetivos pelo lógos e não carecem praticamente de nenhuma ou quase nenhuma ação. É o caso da aritmética, do cálculo, da geometria e, certamente, também do jogo de tabuleiro (petteutikế) e de muitas outras artes em que o lógos desempenha, por vezes, um papel quase igual ao dos atos materiais e, na maioria dos casos, um papel superior, dado que toda a atuação e eficácia se verificam nessas artes por meio do lógos. É ao número dessas últimas que suponho dizes pertencer a retórica. (PLATÃO, Gór. 450 d-e; PLATÃO, 1973, p. 35).

Na República, a lista é diferente e traz os jogos entremeados a diversos conhecimentos técnicos úteis: agricultura, fabricação de sapatos, jogo de um

\footnotetext{
${ }^{7} \mathrm{H}$. Bolkenstein acredita que as competiçóes gregas não devem ser incluídas na moderna categoria "jogo" - "quando aludimos aos Jogos Olímpicos, inadvertidamente, fazemos uso de um termo latino, o qual exprime a apreciação dos romanos sobre as competiçóes assim designadas, que é totalmente diferente da interpretaçấo dos gregos"; o autor conclui, após listar uma longa série de atividades denominadas pelo termo grego agốn: "tudo isso nada tem a ver com o jogo - a menos que se pretenda que para os gregos tudo na vida era jogo!" Johan Huizinga (2001, p. 36) cita a crítica e responde, assinalando que é precisamente essa sua posição.
} 
jogo de tabuleiro, construção civil, tocar um instrumento, criação de cavalos, construção e pilotagem de barcos, vinicultura, arte militar e música (PLATÃO, Rep. I, 333a-e; PLATO, 1994, v.4, p. 26-29). ${ }^{8}$ Em outra passagem, o filósofo ateniense descreveu explicitamente a dialética como um jogo de tabuleiro, incluindo alguns detalhes "táticos":

Sócrates, ninguém seria capaz de contradizer teus argumentos. Mas, via de regra, as pessoas que ocasionalmente te ouvem argumentar sentem-se assim: imaginam que, por não terem experiência na arte de questionar e responder, deixam-se enganar pouco a pouco por cada argumento e, quando esses pequenos desvios se acumulam no final da discussão, grande é sua queda e a aparente contradição a partir do que eles disseram inicialmente; da mesma forma que os jogadores de jogos de tabuleiro hábeis (tồn petteúein deinôn) bloqueiam os inábeis que se veem impossibilitados de fazer um movimento, o teu interlocutor fica bloqueado e náo sabe o que dizer, neste outro jogo de tabuleiro (petteías) que é jogado, não com peças (ouk en pséphois), mas com palavras (PLATO, República, VI, 487ac; PLATO, 1994, v. 5, p. 12-15).

Políbio (c. 203-120 a.C.) elogiou o general cartaginês Amílcar Barca, com uma expressão bem semelhante: "[...] como um bom jogador de jogos de tabuleiro (agathòs petteutès), isolando-os e cercando-os, ele destruiu grandes números sem arriscar um engajamento geral." (POLÍBIO, I, 84 apud AUSTIN, 1940, p. 261).

Lembremo-nos também da série supracitada de vasos áticos que retrata dois guerreiros jogando. $\mathrm{O}$ jogo lá pintado era certamente um jogo de tabuleiro (talvez o jogo das cinco linhas, como já observamos) e seus jogadores não são crianças. A imagem de dois soldados armados jogando um jogo de tabuleiro ocorre já em meados do século VI, em selos esculpidos e alças de escudo encontradas em Egina, Olímpia e perto de Tarento, na Itália. Além desses achados arqueológicos e de 168 vasos já catalogados (152 versóes de figuras negras e 16 de figuras vermelhas), um grupo de estátuas de mármore com a mesma cena parece ter sido consagrado na Acrópole ateniense, antes da invasão persa (KURKE, 1999, p. 261). Nem sempre os guerreiros são identificados, mas em todas as instâncias em que eles o são, são nomeados como Ájax e Aquiles (MARISCAL, 2011, p. 394, n. 2). Ou seja, não se trata

\footnotetext{
${ }^{8}$ Literalmente, Platão escreve pettôn thésin, "colocação de peças", atividade cujo maior especialista é o petteutikós, o "jogador de jogos de tabuleiro".
} 
de guerreiros quaisquer, mas dos dois maiores heróis gregos da Ilíada - e talvez de toda a guerra de Troia - jogando um paidiá.

Assim, paizōn indicava uma criança jogando/brincando, e a etimologia parece indicar que se trata de um jogo/uma brincadeira infantil (como, aliás, muitos intérpretes traduziram e interpretaram essa passagem). Entretanto, pesseúōn desloca a cena para além da infância: a criança joga um jogo difícil, o qual exigia dedicaçáo para dominar a arte (téchnē) de jogar bem, um jogo ordenado, com regras específicas que têm que ser seguidas corretamente e que, metaforicamente, tem ressonâncias cívicas e cósmicas.

\section{Palavras finais}

Evidentemente, essas breves observaçóes não solucionam o sentido de B 52. Ainda é necessário identificar as relaçôes entre a criança e o aión, esse termo complexo que parece referir-se à totalidade do tempo de vida (KEIZER, 2010, cap. 2, passim). Pretendo discutir as relaçóes entre esses termos (e a relação de ambos com a questáo da temporalidade) em um artigo posterior. Se me for possível, almejo ainda tentar comentar as relaçóes do jogo com a temporalidade. Essas elucidaçóes, no entanto, são um trabalho para o futuro. Ainda assim, acredito que as observaçóes aqui expostas podem auxiliar no entendimento desse enigmático quebra-cabeças que vem desafiando os filósofos, há quase dois mil e quinhentos anos.

LOPES, A. P. L. Heraclitus, B 52 DK: a semantic analysis of play. Trans/form/açāo, Marília, v. 44, n. 1, p. 17-34, Jan./Mar., 2021.

\footnotetext{
ABstract: Heraclitus' fragment B 52 DK defines aiốn (time, life, or lifetime) as a playing child. But what is being played? The usual interpretations debase the heraclitic play, listing this fragment among those that criticize the faulty knowledge of mankind. Against these, I propose a philological analysis to better identify and understand what is being played in B 52, in the belief that it is not a childish play, but a serious game that resounds with cosmic and civic metaphors.
}

KeYwords: Game. Heraclitus. Greek philosophy. 


\section{REFERÊNCIAS}

AUSTIN, R. G. Greek board games. Antiquity. Cambridge, v.14, p. 257-271, set. 1940.

BARNES, J. Filósofos pré-socráticos. Tradução de Julio Fischer. São Paulo: Martins Fontes, 1997. Publicado originalmente em 1987.

BOLLACK, J.; WISMANN, H. Héraclite ou la séparation. Paris: de Minuit, 1972.

CAMPOS, H. Heráclito revisitado. Trans/Form/Açáo, Marília, v. 1, p. 217-225, 1974.

CANCIK, H.; SCHNEIDER, H.; LANDFESTER, M. (ed.). Brill's New Pauly. Encyclopædia of the ancient world. Tradução editada por Christine F. Salazar \& Francis G. Gentry. Leida, Holanda: Brill, 2006. Disponível em: https://referenceworks. brillonline.com/browse/brill-s-new-pauly. Acesso em : 28 fev. 2019. Publicado originalmente em 1996.

CHANTRAINE, P. Dictionnaire étymologique de la langue grecque. Histoire des mots. Nova edição com suplemento. Paris: Klincksieck, 1999. Publicado originalmente em 1968.

COLLI, G. La sapienza greca. v. III. Eraclito. Milão: Adelphi, 1980.

CONCHE, M. Héraclite. Fragments. 4. ed. Paris: P.U.F., 1998. Publicado originalmente em 1986.

COSTA, A. Heráclito: fragmentos contextualizados. Rio de Janeiro: DIFEL, 2002.

DIELS, H.; KRANZ, W. Die Fragmente der Vorsokratiker. 9. ed. Berlim:

Weidmannsche, 1960. Publicado originalmente em 1903.

DIÔGENES LAÊRTIOS. Vidas e doutrinas dos filósofos ilustres. Tradução, introdução e notas de Mário da Gama Kury. 2. ed., Brasília: EdUnB, 2008. Publicado originalmente em 1987.

HEIDEGGER, M. Gesamtausgabe. I. Abteilung: veröffentlichte Schriften 19101976. v.10: Der Satz von Grund. Frankfurt sobre o Meno: Vittorio Klostermann, 1997. Publicado originalmente em 1957.

HUIZINGA, J. Homo ludens. O jogo como elemento da cultura. Tradução de João Paulo Monteiro; revisão de Mary Amazonas Leite de Barros. 5. ed. São Paulo: Perspectiva, 2001. Publicado originalmente em 1938.

KAHN, C. H. The art and though of Heraclitus. An edition of the fragments with translation and commentary. Cambridge: Cambridge University Press, 2001. Publicado originalmente em 1979.

KEIZER, H. M. Life time entirety. A study of AION in Greek literature and philosophy, the Septuagint and Philo. Ed. rev. Zoetermeer, Holanda: [s.n.], 2010.

KIRK, G. S. Heraclitus: the cosmic fragments. A critical study with introduction, text and translation. Ed. corr. Cambridge: Cambridge University Press, 1962. 
KURKE, L. Ancient Greek board games and how to play them. Classical Philology, Chicago, IL, v. 94, n. 3, p. 247-267, jul. 1999.

LEBEDEV, A. The cosmos as a stadium: agonistic metaphors in Heraclitus' cosmology. Phronesis, Leida, Holanda, v. 30, n. 2, p. 131-150, 1985.

LUCIAN in eight volumes. v. 2. Texto grego e tradução de A. M. Harmon. Londres: William Heineman/Cambridge, MA: Harvard University Press, 1960. (Loeb Classical Library)

MARCOVICH, M. Heraclitus. Greek text with a short commentary (Editio maior). Mérida, Venezuela: Los Andes University Press, 1967.

MARISCAL, L. R. Ajax and Achilles playing a board game: revisited from the literary tradition. Classical Quarterly, Cambridge, v. 61, n. 2, p. 394-401, dez. 2011.

MOST, G. W. Heraclitus fragment B 52 DK (on OF 242). In: JÁUREGUI, M. H. et al. (ed.). Tracing Orpheus: studies of orphic fragments. Berlim: de Gruyter, 2001. p. 105110. (Sozomena. Studies in the recovery of ancient texts; v. 10)

OS PRÉ-SOCRÁTICOS. Fragmentos, doxografia e comentários. Seleção de textos e supervisão de José Cavalcante de Souza; tradução dos fragmentos de Heráclito por José Cavalcante de Souza. Sáo Paulo: Nova Cultural, 1996. (Os pensadores). Publicado originalmente em 1978.

PLATÃO. As leis. Incluindo Epinomis. Tradução de Edson Bini. 2. ed., São Paulo: Edipro, 2010.

PLATÃO. Górgias. O banquete. Fedro. Tradução de Manuel de Oliveira Pulquério, Maria Teresa Schiappa de Azevedo e José Ribeiro Ferreira. Lisboa: Verbo, 1973. (Clássicos gregos e latinos)

PLATO; v. 5-6. The Republic. Texto grego e tradução de Paul Shorey. Cambridge, MA: Harvard University Press, 1994. Publicados originalmente em 1930 e 1935. (Loeb Classical Library)

RAMNOUX, C. Héraclite, ou l'homme entre les mots et les choses. Paris: Les Belles Lettres, 1959.

ŠĆEPANOVIĆ, S. Heraclitus' Fragment B 52 DK Re-examined. Rhizomata: a journal for ancient philosophy and science, Berlim, v. 3, n. 1, p. 26-46, 2015.

SILVA, M. R. C. Densidade semântica e jogos de linguagem nos fragmentos de Heráclito de Éfeso. 2013, 111 f. Dissertação (Mestrado em Letras) - Programa de PósGraduação em Estudos Literários, Belo Horizonte, 2013.

THEOCRITUS. v.1. Edição, tradução e comentário de A. S. F. Gow. Cambridge: Cambridge University Press, 1973. Publicado originalmente em 1950.

Recebido: 26/4/2019

Aceito: 04/7/2020 
LOPES, A. P. L. 